\title{
Content copyrights and signal copyrights: the case for a rational scheme of protection*
}

\author{
Richard Arnold \\ Judge of the High Court of Justice of England and Wales, Chancery Division
}

\section{INTRODUCTION}

Categorisation of subject matter is an important aspect of the law of copyright and related rights. This is not merely from a technical point of view. Whether under the international treaties, common law copyright systems or civil law author's right and neighbouring right systems, categorisation affects the substantive rights conferred. In this article, I shall explain the distinctions between two categories of copyrights recognised by United Kingdom law, namely content copyrights and signal copyrights, and I shall argue that UK law in this area suffers from two problems. Addressing these problems would promote a more rational scheme of protection, as well as enabling a more accurate implementation by the UK of the EU copyright directives.

\section{TWO KEY DISTINCTIONS}

It is important to begin by recognising two key distinctions. The first is the distinction between content and signal or message and medium. Thus we need to distinguish between a literary work (content) and the paper it is printed on (signal); between a musical work (content) and the sound recording which embodies it (signal); between an audiovisual work (content) and the celluloid which fixes it (signal); and between a dramatic work (content) and the broadcast which diffuses it (signal).

The second distinction is between copying the content and copying the signal. Here we need to distinguish between transcription, translation or adaptation of a literary work (copying the content) and photocopying a book containing that literary work (copying the signal); between the performance or arrangement of a musical work (copying the content) and copying a compact disc bearing that musical work (copying the signal); between re-shooting a film ${ }^{1}$ (copying the content) and copying a DVD which includes the film (copying the signal); and between the performance or adaptation of a dramatic work (copying the content) and home taping a broadcast of that work (copying the signal).

It will be appreciated that copying the signal necessarily involves copying the content, but copying the content does not necessarily involve copying the signal.

* This article is based on a lecture delivered at the London School of Economics on 1 February 2010.

1. For example, as in Gus Van Sant's shot-for-shot remake (1998) of Alfred Hitchcock's Psycho (1960). 


\section{COPYRIGHTS VERSUS AUTHORS' RIGHTS AND NEIGHBOURING OR RELATED RIGHTS}

Next we need to remind ourselves of the difference between 'copyrights' in English law and 'authors' rights' (droits d'auteur or Urheberrechte) in civil law systems. In simple terms, civil law systems use the term 'authors' rights' to refer to the rights of individual authors in their works. In those systems, other types of right, such as the rights of corporations in sound recordings and broadcasts, are typically not regarded as authors' rights, but as neighbouring rights (droits voisins) or related rights (verwandte Schutzrechte). By contrast, in English law all such rights are termed 'copyrights'. It would be a mistake to suppose, however, that, just because all such rights are called copyrights in English law, they all have the same content, any more than they do in civil law systems. As we shall see, they do not.

\section{THE INTERNATIONAL TREATIES}

Copyright law is based on the framework provided by a series of international treaties. These treaties categorise the subject matter protected, in particular by requiring some types of subject matter to be protected by copyright (ie authors' rights in civil law terminology) while permitting other types of subject matter to be protected in other ways (ie by neighbouring or related rights in civil law terminology).

\section{The Berne Convention}

The Berne Convention for the Protection of Literary and Artistic Works ${ }^{2}$ requires countries of the Union to confer copyright (ie authors' rights) on 'literary and artistic works'. Article 2(1) provides:

The expression 'literary and artistic works' shall include every production in the literary, scientific and artistic domain, whatever may be the mode or form of its expression, such as books, pamphlets and other writings; lectures, sermons and other works of the same nature; dramatic or dramatico-musical works; choreographic works and entertainments in dumb show; musical compositions with or without words; cinematographic works to which are assimilated works expressed by a process analogous to cinematography; works of drawing, painting, architecture, sculpture, engraving and lithography; photographic works to which are assimilated works expressed by a process analogous to photography; works of applied art; illustrations; maps, plans, sketches and three-dimensional works relative to geography, topography, architecture or science.

The definition of 'literary and artistic works' contained in Article 2(1) is expansive and open-ended. Moreover, it expressly includes 'cinematographic works' and 'photographic works'. Nevertheless, it is conventionally understood not to include sound recordings or broadcasts. ${ }^{3}$ It follows that the Berne Convention does not require sound

\section{Paris Act, 1971.}

3. See eg Ricketson and Ginsburg, International Copyright and Neighbouring Rights: The Berne Convention and Beyond (2nd edn, Oxford University Press, Oxford 2007), 505-8, 1205-8; Goldstein and Hugenholtz, International Copyright: Principles, Law and Practice (2nd edn, Oxford University Press, Oxford 2010), 104, 156, 186-9; Ficsor, Guide to the Copyright and Related Rights Treaties Administered by WIPO (WIPO, 2003), 27. 
recordings or broadcasts to be protected by copyrights (ie authors' rights), although it leaves Union members free to confer copyright status on such works if they so wish.

\section{The Rome Convention}

The Rome Convention on the Protection of Performers, Phonogram Producers and Broadcasting Organisations of 1961 lays down minimum standards of protection for performers, phonogram producers and broadcasting organisations. For present purposes the precise definitions of the protected types of subject matter do not matter. The point to note is that the Rome Convention does not require the grant of copyrights (ie authors' rights as opposed to neighbouring or related rights). ${ }^{4}$

\section{The WIPO Treaties}

Article 3 of the WIPO Copyright Treaty provides that Article 2 of the Berne Convention applies. Thus the WIPO Copyright Treaty does not require sound recordings and broadcasts to be protected by copyrights (ie authors' rights) either.

The WIPO Performances and Phonograms Treaty upgrades the minimum standards provided by the Rome Convention for performers and phonogram producers, but still does not require the grant of copyrights (ie authors' rights as opposed to neighbouring or related rights).

The proposed (but presently stalled) WIPO Broadcasting Treaty would upgrade the minimum standards provided by the Rome Convention for broadcasting organisations, but would not require the grant of copyrights (ie authors' rights as opposed to neighbouring or related rights).

\section{THE EU COPYRIGHT DIRECTIVES}

The European Union has enacted a series of harmonising directives in the field of copyright and related rights. Several of these directives differentiate between the different kinds of rights which they provide for in a manner which reflects the distinctions drawn by civil law systems between authors' rights and neighbouring or related rights.

The pattern was established by the first major directive, Council Directive 92/100/EEC of 19 November 1992 on rental right and lending right and on certain rights related to copyright in the field of intellectual property, now codified as Parliament and Council Directive 2006/115/EC of 12 December 2006 ('the Related Rights Directive'). This requires the grant of various rights to:

- 'the author' in respect of 'the original and copies of his work' (Art 3(1)(a));

- 'the phonogram producer' in respect of 'his phonograms' (Arts 3(1)(c) and 9(1)b));

- 'the producer of the first fixation of a film' in respect of 'the original and copies of his film' (Arts 3(1)(d) and 9(1)(c)); and

- 'broadcasting organisations' in respect of 'fixations of their broadcasts' and 'rebroadcasting of their broadcasts' (Arts 7(2), 8(3) and 9(1)(d)).

4. See eg Arnold, Performers' Rights (4th edn, Sweet \& Maxwell, London 2008), 20-23; Ricketson and Ginsburg 1210-16; Goldstein 54-7; Ficsor 133-4. 
It can be seen from this that the Related Rights Directive differentiates between authors and their works on the one hand and phonogram producers, film producers and broadcasting organisations and their phonograms, fixations and broadcasts on the other hand. Although not spelt out, it appears that authors' works for the purposes of the Related Rights Directive are literary and artistic works within the meaning of Article 2(1) of the Berne Convention. ${ }^{5}$ Thus the Related Rights Directive permits Member States to protect authors' works by copyright (ie authors' rights) and the other types of subject matter by neighbouring or related rights.

Similarly, European Parliament and Council Directive 2001/29/EC of 22 May 2001 on the harmonisation of certain aspects of copyright and related rights in the information society ('the Information Society Directive') requires the grant of rights to:

- 'authors' in respect of 'their works' (Arts 2(a), 3(1) and 4(1));

- 'phonogram producers' in respect of 'their phonograms' (Arts 2(c) and 3(2)(b));

- 'producers of the first fixations of films' in respect of 'the original and copies of their films' (Arts. 2(d) and 3(2)(c)); and

- 'broadcasting organisations' in respect of 'fixations of their broadcasts' (Arts 2(e) and 3(2)(d)).

Again, the same distinction is made. Here, it seems even clearer that authors' works for the for the purposes of the Information Society Directive are literary and artistic works within the meaning of the Berne Convention, since recital (15) makes it clear that the Information Society Directive is intended to give effect to the WIPO Copyright Treaty.

Finally, Council Directive 93/98/EEC of 29 October 1993 on the term of protection of copyright and certain related rights, now codified as Parliament and Council Directive 2006/116/EC of 12 December 2006 ('the Term Directive'), requires Member States to confer:

- 70 years post mortem auctoris term of protection for "the rights of an author of a literary or artistic work within the meaning of the Article 2 of the Berne Convention' (Art 1(1));

- 70 years term of protection for rights in 'cinematographic or audiovisual works' measured from the last to die of various contributors (Art 2(2)); and

- 50 years term of protection measured from various starting points for 'the rights of producers of phonograms', 'the rights of producers of the first fixation of a film' and 'the rights of broadcasting organisations' (Art 3(2), (3) and (4)).

Thus the Term Directive makes the same distinction as the other directives, with the addition of a refinement to deal with 'cinematographic or audiovisual works' as a special category of works of joint authorship. In this case, it is explicit that literary and artistic works are those which fall within Article 2(1) of the Berne Convention.

5. See Reinbothe and von Lewinski, The EC Directive on Rental and Lending Rights and on Piracy (Sweet \& Maxwell, London 1993), 46. 


\section{UK COPYRIGHT, DESIGNS AND PATENTS ACT 1988}

Section 1(1) of the Copyright, Designs and Patents Act 1988 differentiates between two basic categories of subject matter. The first category, which is specified in section $1(1)(a)$, is 'original literary, dramatic, musical or artistic works'. This category consists of contents: the works are protected regardless of the signals by which they are carried. It should be noted, however, that section 4(1)(a) defines 'artistic work' as meaning inter alia 'a photograph'. The second category, which is specified in section 1(1)(b) and (c), is 'sound recordings, films or broadcasts' and 'the typographical arrangement of published editions'. This category consists of signals: what is protected is the signal itself, as distinct from the content it carries. That is why there is no requirement of originality.

If section 1(1) of the 1988 Act is compared with Article 2(1) the Berne Convention, it appears to be broadly consistent in that most 'literary and artistic works' within Article 2(1) will qualify as 'literary, dramatic, musical or artistic works' within section 1(1)(a). It may be questioned, however, how the UK complies with the Berne requirement to protect cinematographic works as literary and artistic works, when there is no mention of such works in section 1(1)(a), and 'films' fall within section 1(1)(b). I shall return to this point below.

\section{CONTENT COPYRIGHTS AND SIGNAL COPYRIGHTS IN UK LAW}

It is trite law that copyrights in literary, dramatic, musical and artistic works (ie contents) may be infringed without copying the signal or medium on which the work was recorded by the author or published by the publisher, if different. By contrast, copyrights in sound recordings, films, broadcasts and published editions (ie signals) can only be infringed by copying the signal produced by the 'author'. This point is demonstrated by three leading cases. In CBS Records Australia Ltd v Telmak Teleproducts (Australia) Pty Ltd ${ }^{6}$ it was held that a sound recording copyright is only infringed if there has been copying of part of the recording itself, and it is not an infringement to reproduce the sound of the recording without copying the recording. In Telmak Teleproducts Australia Pty Ltd $v$ Bond International Pty Ltd ${ }^{7}$ and Norowzian $v$ Arks Ltd (No 1$)^{8}$ it was held that copyright in a film is only infringed if there has been 'photographic' copying of part of the film, and it is not an infringement to reproduce the content of the film by 'non-photographic' copying. Although there does not appear to be any decided case on the point, it is clear that the same principle must apply to a broadcast. As for published editions, section 17(5) of the 1988 Act expressly requires a facsimile copy in order for the copyright in a published edition to be infringed.

\section{PROBLEM (1): THE PRESENT UK SCHEME DRAWS THE LINE IN THE WRONG PLACE}

The distinction made by UK law between content copyrights and signal copyrights is

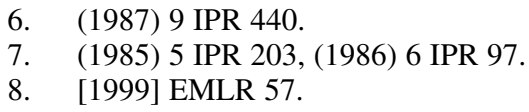


a perfectly rational one. Content copyrights protect the creativity of authors expressed in their works. Such creativity merits protection from unauthorised exploitation regardless of the medium in which the work happens to be embodied at any one moment. By contrast, signal copyrights protect investment in producing a signal. That investment merits protection from free-riding, but a more limited degree of protection than that required by authors' works.

The first problem with UK law is that, although the principle of distinguishing between content rights and signal rights is a sound one, the present scheme draws the line in the wrong place in two ways. First, the effect of section 4(1)(a) is that photographs are protected as content when they should be protected as signals. Taking a photograph only requires the pressing of a button. What should be protected is the investment of the photographer. Protecting photographs as content leads to overprotection: the problem exemplified by the famous case of Bauman v Fussell. ${ }^{9}$ In that case a majority of the Court of Appeal held that a painting of two cocks fighting did not infringe the copyright in a photograph from which the position of cocks had been taken on the ground that, as the trial judge held, there was no reproduction of a substantial part of the photograph. There was no dispute, however, that in principle a claim for infringement could lie if the painting did reproduce a substantial part of the photograph. While the photographer deserved protection for his signal, since he invested not only in equipment and film but also in being in the right place at the right time, he did not create the position of the cocks and thus did not merit a right extending that far. Paradoxically, this problem is combined with underprotection of unconventional artistic works: the problem exemplified by Creation Records Ltd v News Group Newspapers Ltd. ${ }^{10}$ In that case Lloyd J (as he then was) held that a scene devised for the purposes of a photograph for a pop group's album cover was neither a sculpture nor a collage nor a work of artistic craftsmanship, and hence unprotected by copyright. On this basis, much contemporary art is at risk of being unprotected by UK copyright law. ${ }^{11}$

The solution to this aspect of the problem is to have a content right for any original artistic work captured or capable of being captured in a photograph and a signal right for all photographs. It is suggested that this would be Berne-compliant. Indeed, it is arguable that it goes further than Berne requires, since Berne only requires protection for 'photographic works', and not every photograph constitutes an author's work. ${ }^{12}$

Secondly, UK law protects films as signals. The content of the film is protected only if and to the extent that it qualifies as a dramatic work: Norowzian v Arks Ltd (No 2). ${ }^{13}$ As that case demonstrates, this leads to underprotection, since a film-maker's visual (as opposed to dramatic) creativity is not protected against non-photographic copying.

The solution to this aspect of the problem is to have a content right for any audiovisual work captured or capable of being captured in a film, and a signal right for the film itself as at present. It is suggested that this would not only be Berne-compliant, but also rather more clearly so than the current system.

9. [1978] RPC 485 .

10. [1997] EMLR 444.

11. Compare, for example, the position in German law exemplified by the decision of Bundesgerichsthof in Wrapped Reichstag [2003] ECDR 7.

12. See Arnold, 'Copyright in Photographs: A Case for Reform' [2005] EIPR 303.

13. [2000] EMLR 67. 


\section{PROBLEM (2): INCORRECT UK IMPLEMENTATION OF EU COPYRIGHT DIRECTIVES}

The 1988 Act has repeatedly been amended by statutory instruments made under section 2 of the European Communities Act 1972 to implement the EU copyright directives. The manner in which these directives have been implemented, however, does not correctly reflect the division between the different types of rights which the directives require to be conferred.

In the case of films, the Related Rights Directive, the Term Directive and the Information Society Directive provide for two different classes of subject matter, which have different authors/rightholders, attract different rights and are protected for different terms. The first class is 'cinematographic or audiovisual works':

- Authors: must include the principal director, but may include other authors (Art 2(1), Term Directive).

- Rights: reproduction right, distribution right, rental and lending rights, communication to the public right (Art 3(1)(a), Related Rights Directive, Arts. 2(a), 3(1) and 4(1) Information Society Directive).

- Term: 70 years from death of last to die of principal director, author of screenplay, author of dialogue and composer of music specifically created for use in cinematographic or audiovisual work (Art 2(2), Term Directive).

The second class is 'first fixations of films':

- Rightholder: producer (all three Directives).

- Rights: reproduction right, distribution right, rental and lending rights, making available right (Arts. 3(1)(d) and 9(1)(c) Related Rights Directive, Arts 2(d) and 3(2) Information Society Directive).

- Term: 50 years from fixation or publication or communication to public (Art 3(3) Term Directive).

These Directives were implemented by the Duration of Copyright and Rights in Performance Regulations 1995, ${ }^{14}$ the Copyright and Related Rights Regulations $1996^{15}$ and the Copyright and Related Rights Regulations 2003. ${ }^{16}$ The amendments made to the 1988 Act by these Regulations do not reflect the distinction drawn by the Directives between cinematographic or audiovisual works on the one hand and first fixations of films on the other hand, however. Indeed, even as amended, the 1988 Act contains no category of works corresponding to cinematographic or audiovisual works. What the 1988 Act calls a 'film' is what the Directives call a 'first fixation of a film', and as discussed above the copyright in a film is a signal copyright. Although the decision of the Court of Appeal in Norowzian (No. 2) means that the dramatic content of a film will be protected as a dramatic work, this only partially fills the lacuna for the reason discussed above. Furthermore, there remains a more fundamental problem with the implementation, which is that section 13B of the 1988 Act ascribes to the film copyright the dura-

14. SI 1995, No 3297.

15. SI 1996, No 2967.

16. SI 2003, No 2498. 
tion which should be ascribed to the rights in the cinematographic or audiovisual work. ${ }^{17}$

If the 1988 Act were to be replaced by a new statute framed in the manner suggested above, it would enable this problem to be solved as well.

\section{CONCLUSION}

Although there is nothing inherently wrong with the distinction drawn by the 1988 Act between content copyrights and signal copyrights, the present statutory framework is flawed. Addressing the problems outlined above would lead to a more rational scheme, as well as more faithfully implementing the UK's obligations under the EU copyright directives.

17. See Kamina, 'British Film Copyright and the Incorrect Implementation of the EC Copyright Directives' [1998] Ent LR 109; Arnold, ‘Joy: A Reply’ [2001] IPQ 10. 